Collection: COST Action FP0905

"Biosafety of forest transgenic trees and EU policy directives"

Guest Editors: Cristina Vettori, Matthias Fladung

\section{Comparative analysis of students' attitudes toward implementation of genetically modified trees in Serbia}

\author{
Marina Nonić ${ }^{(1)}$, Uroš Radojević ${ }^{(2)}$, Jelena Milovanović ${ }^{(2)}$, \\ Marko Perović (1), Mirjana Šijačić-Nikolić ${ }^{(1)}$
}

Genetically-modified (GM) trees represent a new frontier in biotechnology, though many environmental concerns associated to the commercial use of GM trees and their products have been recently raised. In general, GM trees involve no safety issues related to human health, therefore public attitudes toward their commercial use should depend on environmental concerns or personal philosophical viewpoints, but also on educational level and background. To assess the relevance of the educational level and background on attitudes toward acceptance of commercial GM tree cultivation, a survey was conducted in January 2014 among 400 students from the Faculty of Forestry of the University of Belgrade and from the Faculty of Applied Ecology "Futura" at the University Singidunum (Belgrade). The aim was to determine whether different educational profiles and educational level significantly affect students' attitudes toward GM trees. Results showed no significant differences in the responses among students from both faculties. All students showed a good knowledge of GM trees and agreed that different genetic modifications of forest trees would be very important for their country. Also, more than a half of students from both faculties would agree with commercial planting of GM trees and would purchase their final products. However, 70 to $90 \%$ of students from both faculties considered the hazards associated with the commercial use of GM trees as "serious hazard" or "slight hazard". The implication of the above results are discussed.

Keywords: Genetic Modifications, Forest Trees, Biotechnology, Survey

\begin{abstract}
Introduction
Interest in genetically modified organisms is constantly increasing due to both scientific and commercial reasons. Thanks to recent advances in the field of biotechnology, several genetically modified (GM) agricultural crops are currently grown worldwide, such as soybean, maize, cotton, sugar beet, tomato and others. The next frontier in biotechnology is represented by the genetic modification of forest trees aimed at different pur-
\end{abstract}

poses, such as faster growth, easier wood or biofuel processing, altered wood structure, resistance to herbicides and pests, etc. Besides the obvious commercial advantages, environmental benefits of the cultivation of GM trees have been claimed, such as an enhanced sequestration of $\mathrm{CO}_{2}$ by fast-growing trees, protection of soil and water resources, and habitat provision for wildlife (Milovanović \& Sijačić-Nikolić 2006). Despite the introduction of GM trees has started only

(1) Faculty of Forestry, University of Belgrade, Belgrade (Serbia); (2) Faculty of Applied Ecology "Futura", Singidunum University, Belgrade (Serbia)

@ Uroš Radojević (uros.radojevic@futura.edu.rs)

Received: Apr 03, 2014 - Accepted: Aug 09, 2014

Citation: Nonić M, Radojević U, Milovanović J, Perović M, Šijačić-Nikolić M, 2015. Comparative analysis of students' attitudes toward implementation of genetically modified trees in Serbia. iForest 8: 714-718 [online 2015-01-08] URL: http://www.sisef.it/ iforest/contents/?id=ifor1305-007

Communicated by: Elena Paoletti in recent times, GM tree plantations have been already established in many parts of the world (Harfouche et al. 2011, Nonić et al. 2012).

Several studies has focused on possible environmental risks and impacts associated to the cultivation of GM trees (Steinbrecher \& Lorch 2008, Häggman et al. 2013) due to several characteristics of their life cycle, such as long-distance pollination, sexual compatibility with wild relatives, reproduction by vegetative propagation, etc. For the above reasons, in most countries field experiments on transgenic trees are subject to a strict regulation, including the destruction of trees before seed production, spatial separation from stands of the same or interfertile species, planting of border rows/pollen traps, or even restriction of GM cultivation to laboratories and greenhouses.

Currently, only few GM tree species have been licensed for commercial planting throughout the world. For instance, the European black poplar, engineered with an insecticidal gene from the soil bacterium Bacillus thuringiensis $(\mathrm{Bt})$, is being widely grown in China with more than one million trees planted on hundreds of hectares since 2003 (FAO 2004). However, commercial products from GM trees are not expected to be available on the market in short time. Unlike GM food crops, GM tree products do not imply issues related with human health. Therefore, their acceptance by consumers largely depend on personal attitudes, like environmental concerns or philosophical viewpoints, but also on the educational level and personal knowledge background.

In this study, a survey among university students from Belgrade (Serbia) was carried out in order to assess the relevance of educational level and background on attitudes toward acceptance of the commercial use of GM trees, and their final products.

\section{Methods}

A survey was conducted in January 2014 among the students of the Faculty of Forestry, University of Belgrade, and the Faculty of Applied Ecology, Futura University Singidunum (Belgrade). These faculties were chosen because of the difference in their study programs, focused on forestry sciences and environmental sciences, respectively, with the aim of determining whether contrasting educational profiles significantly affect attitudes of students toward GM trees. Students from the faculty of Forestry take a course of genetics during the second year of studies, while those from the faculty of Applied Ecology learn about GM trees within the "Protection of endangered species" course on the second year and "Protection of forest ecosystems" on the third year.

A questionnaire was submitted to a total of 
Tab. 1 - Survey results on knowledge about GM trees and their application

\begin{tabular}{lllrr}
\hline Questions & Faculty & Answer & Freq. & Percent \\
\hline Q1.1 Do you know what a geneti- & Forestry & Yes & 165 & 82.5 \\
cally modified forest tree (trans- & & No & 35 & 17.5 \\
genic forest tree) is? & & Total & 200 & 100 \\
\cline { 2 - 5 } & Applied & Yes & 145 & 72.5 \\
& Ecology & No & 55 & 27.5 \\
& & Total & 200 & 100 \\
\hline Q1.2 Do you know if transgenic & Forestry & Yes & 103 & 51.5 \\
forest plantations are grown com- & & No & 97 & 48.5 \\
mercially? & & Total & 200 & 100 \\
\cline { 2 - 5 } & Applied & Yes & 88 & 44 \\
& Ecology & No & 112 & 56 \\
& & Total & 200 & 100 \\
\hline Q1.3 Do you know if final pro- & Forestry & Yes & 132 & 66 \\
ducts of transgenic forest planta- & & No & 68 & 34 \\
tions (wood, biofuel, pulp, paper) & & Total & 200 & 100 \\
\cline { 2 - 5 } are sold in the market (stores, & Applied & Yes & 110 & 55 \\
supermarkets etc.)? & Ecology & No & 90 & 45 \\
& & Total & 200 & 100 \\
\hline
\end{tabular}

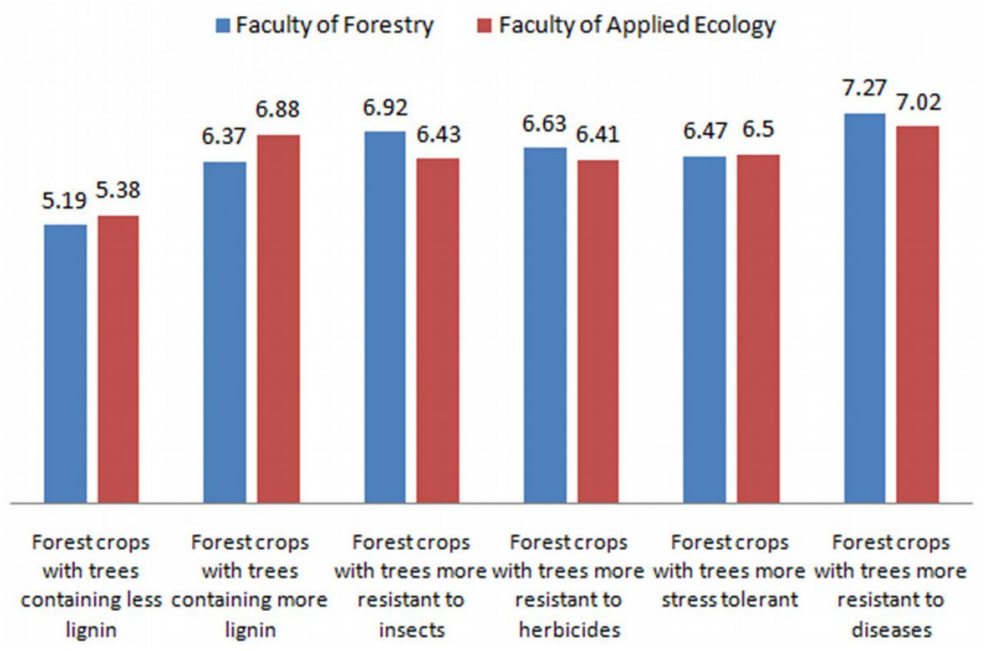

Fig. 1 - Survey results on forestry and applied ecology students' average ranks for acceptability toward different tree genetic modifications

400 students, 200 for each faculty, including students from all the 4 years of the study course, 50 from each year per faculty. The questionnaire had 10 questions of different

types (close, multiple-answers or ranking using a Likert scale) related to: (1) personal socio-economic background; (2) knowledge about GM forest trees; (3) acceptance of GM forest trees products; (4) perceptions of safety issues related to GM forest trees (Nonić et al. 2014).

Data from all the 400 questionnaires were then gathered and analyzed using the statistical software SPSS ${ }^{\circledR}$ ver. 20.0 (IBM 2011). Differences in the attitude toward GM trees among students with different educational level or background were compared by Chisquare test $(\alpha=0.05)$, Linear-by-Linear Association test and computing the Likelihood Ratio.

\section{Results and discussion}

Respondents from the faculty of Forestry were $71.5 \%$ males and $28 \%$ females (missing data: $0.5 \%$ ), while those from the faculty of Applied Sciences were 57\% males, $42 \%$ females (missing data: $1 \%$ ).

The first group of questions was aimed at establishing the level of knowledge of GM trees and their commercial applications:

- Q1.1 "Do you know what a genetically modified forest tree is?"

- Q1.2 "Do you know if transgenic forest plantations are grown commercially?"

- Q1.3 "Do you know if final products of transgenic forest plantations (wood, biofuel, pulp, paper) are sold in the market (stores, supermarkets etc.)?"

Most respondents from both faculties (over $70 \%$, in particular $82.5 \%$ for Forestry and $72.5 \%$ for Applied Ecology) declared that they know what is a GM tree (question Q1.1 - Tab. 1). On the other hand, commercial application and final products of GM trees were less known, as revealed by the lower percentage of positive answers (about 50\%) to questions Q1.2 and Q1.3 (Tab. 1).

In the first year of the study course, $46 \%$ of students from the faculty of Applied ecology and $64 \%$ of the faculty of Forestry stated to know about GM trees, while this percentage increases in the fourth year up to $88 \%$ and $86 \%$, respectively. Results of the Chi-square test of independence showed a highly significant relationship $(p<0.001)$ between the year of study and the knowledge of GM trees for both faculties (Tab. 2).

Tab. 2 - Results of the relationship between educational level of forestry and applied ecology students and their knowledge about GM trees. The question was Q1.1 "Do you know what a genetically modified forest tree (transgenic forest tree) is"? (a): min. expected counts = 8.75; (b): min. expected counts $=13.75$. (Prob): asymptotic significance (2-sided).

\begin{tabular}{|c|c|c|c|c|c|c|c|c|c|}
\hline \multirow{2}{*}{ Faculty } & \multirow{2}{*}{$\begin{array}{c}\text { Year of } \\
\text { study }\end{array}$} & \multicolumn{2}{|c|}{ Yes } & \multicolumn{2}{|c|}{ No } & \multicolumn{4}{|l|}{ Chi-square tests } \\
\hline & & Freq & $\%$ & Freq & $\%$ & Statistics & Value & df & Prob \\
\hline \multirow[t]{5}{*}{ Forestry } & 1 & 32 & 64.0 & 18 & 36.0 & Pearson's Chi-Square & $17.281^{\mathrm{a}}$ & 3 & 0.001 \\
\hline & 2 & 43 & 86.0 & 7 & 14.0 & Likelihood Ratio & 16.459 & 3 & 0.001 \\
\hline & 3 & 47 & 94.0 & 3 & 6.0 & Linear-by-Linear Association & 9.435 & 1 & 0.002 \\
\hline & 4 & 43 & 86.0 & 7 & 14.0 & No. of valid cases & 200 & - & - \\
\hline & Total & 165 & 82.5 & 35 & 17.5 & - & - & - & - \\
\hline Applied & 1 & 23 & 46.0 & 27 & 54.0 & Pearson's Chi-Square & $26.959^{\mathrm{b}}$ & 3 & 0.000 \\
\hline \multirow[t]{4}{*}{ Ecology } & 2 & 36 & 72.0 & 14 & 28.0 & Likelihood Ratio & 26.318 & 3 & 0.000 \\
\hline & 3 & 42 & 84.0 & 8 & 16.0 & Linear-by-Linear Association & 23.760 & 1 & 0.000 \\
\hline & 4 & 44 & 88.0 & 6 & 12.0 & No. of valid cases & 200 & - & - \\
\hline & Total & 165 & 145 & 72.5 & 55 & - & - & - & - \\
\hline
\end{tabular}


Tab. 3 - Survey results on students' attitudes towards the importance of benefits that would be achieved through adoption of GM forest trees.

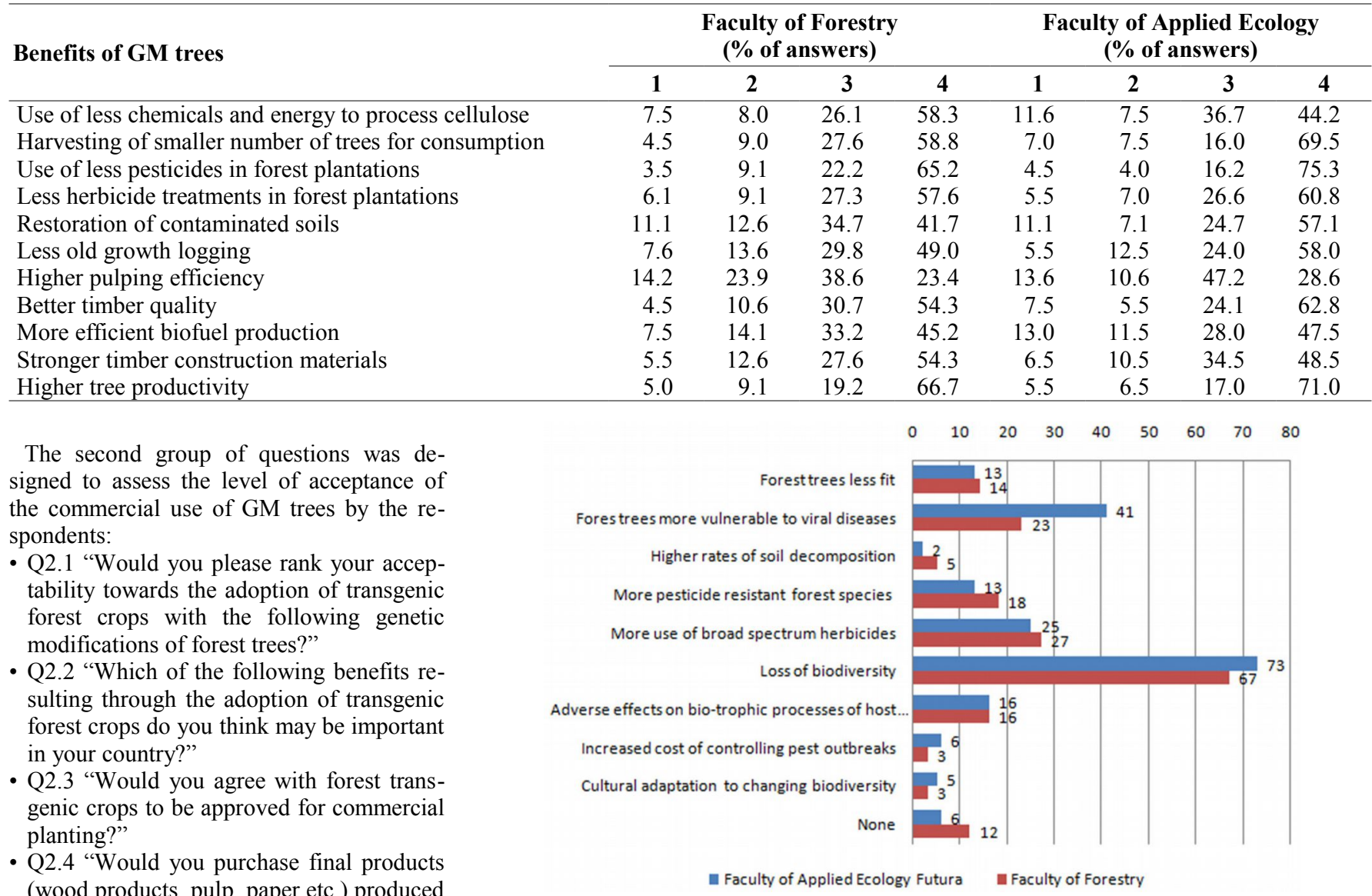
from transgenic forest plantations?"

- Q2.5 "Would you agree with the final products from transgenic forest plantations to be labeled to indicate their origin from genetically modified trees?"

- Q2.5.a "If YES, would you agree with the labeling of such products to be legally mandatory?"

As for question Q2.1, students were asked for ranking on a scale 1 to 10 the acceptability of different genetic modifications of forest trees, including lignin content, resistance to pests, diseases, stress and herbicides. Mean ranks over both faculties for each genetic modification proposed are displayed in Fig. 1. Genetic modifications aimed at enhancing the resistance of trees to diseases was the most acceptable for students from both faculties. However, their opinion varied along the course of studies: $38 \%$ of students in the first year, but only $16 \%$ in the fourth year of studies for the faculty of Applied Ecology, while for the faculty of Forestry $38 \%$ in both the first and fourth year, but $32 \%$ and $30 \%$ in the second and third year. Overall, all the genetic modifications listed in the questionnaire ranked between 5 and 7 , indicating a quite high level of acceptance of various GM tree applications by students.

Students' attitudes about the importance of

Fig. 2 - Results of the survey on attitudes of students toward safety issues of the use of GM trees.

Tab. 4 - Results of the survey on students' acceptance of the commercial use of GM trees.

\begin{tabular}{|c|c|c|c|c|}
\hline Question & Faculty & Answer & Freq & Percent \\
\hline \multirow{6}{*}{$\begin{array}{l}\text { Q2.3 Would you agree with forest } \\
\text { transgenic crops to be approved } \\
\text { for commercial planting? }\end{array}$} & Forestry & Yes & 117 & 58.5 \\
\hline & & No & 82 & 41 \\
\hline & & Total & 199 & 99.5 \\
\hline & Applied & Yes & 112 & 56 \\
\hline & Ecology & No & 88 & 44 \\
\hline & & Total & 200 & 100 \\
\hline \multirow{6}{*}{$\begin{array}{l}\text { Q2.4 Would you purchase the final } \\
\text { products (wood products, pulp, } \\
\text { paper etc.) produced from trans- } \\
\text { genic forest plantations? }\end{array}$} & Forestry & Yes & 109 & 54.5 \\
\hline & & No & 90 & 45 \\
\hline & & Total & 199 & 99.5 \\
\hline & Applied & Yes & 125 & 62.5 \\
\hline & Ecology & No & 75 & 37.5 \\
\hline & & Total & 200 & 100 \\
\hline \multirow{6}{*}{$\begin{array}{l}\text { Q2.5 Would you agree with the } \\
\text { final products produced from } \\
\text { transgenic forest plantations to be } \\
\text { labeled to indicate that they origi- } \\
\text { nate from genetically modified } \\
\text { trees? }\end{array}$} & Forestry & Yes & 178 & 89 \\
\hline & & No & 21 & 10.5 \\
\hline & & Total & 199 & 99.5 \\
\hline & Applied & Yes & 174 & 87 \\
\hline & Ecology & No & 25 & 12.5 \\
\hline & & Total & 199 & 99.5 \\
\hline \multirow{6}{*}{$\begin{array}{l}\text { Q2.5.a If YES, would you agree } \\
\text { with the labeling of such products } \\
\text { to be legally mandatory? }\end{array}$} & Forestry & Yes & 168 & 84 \\
\hline & & No & 28 & 14 \\
\hline & & Total & 196 & 98 \\
\hline & Applied & Yes & 173 & 86.5 \\
\hline & Ecology & No & 13 & 6.5 \\
\hline & & Total & 186 & 93 \\
\hline
\end{tabular}


Tab. 5 - Results of the correlation analysis between educational level of students and their acceptance of GM trees commercial application. The question was: Q2.3. "Would you agree with forest transgenic crops to be approved for commercial planting?". (a): the minimum expected count was 20.19; (b): the minimum expected count was 22.0; (Prob): asymptotic significance (2-sided).

\begin{tabular}{|c|c|c|c|c|c|c|c|c|c|}
\hline \multirow{2}{*}{ Faculty } & \multirow{2}{*}{$\begin{array}{c}\text { Year of } \\
\text { study }\end{array}$} & \multicolumn{2}{|c|}{ Yes } & \multicolumn{2}{|c|}{ No } & \multicolumn{4}{|l|}{ Chi-square tests } \\
\hline & & Freq & $\%$ & Freq & $\%$ & Statistics & Value & df & Prob. \\
\hline \multirow[t]{5}{*}{ Forestry } & 1 & 35 & 70.0 & 15 & 30.0 & Pearson's Chi-Square & $5.226^{\mathrm{a}}$ & 3 & 0.156 \\
\hline & 2 & 31 & 62.0 & 19 & 38.0 & Likelihood Ratio & 5.289 & 3 & 0.152 \\
\hline & 3 & 24 & 49.0 & 25 & 51.0 & Linear-by-Linear Association & 3.802 & 1 & 0.051 \\
\hline & 4 & 27 & 54.0 & 23 & 46.0 & $\mathrm{~N}$ (valid cases) & 199 & - & - \\
\hline & Total & 117 & 58.8 & 82 & 41.2 & - & - & - & - \\
\hline Applied & 1 & 31 & 62.0 & 19 & 38.0 & Pearson's Chi-Square & $1.623^{\mathrm{b}}$ & 3 & 0.654 \\
\hline \multirow{4}{*}{ Ecology } & 2 & 29 & 58.0 & 21 & 42.0 & Likelihood Ratio & 1.627 & 3 & 0.653 \\
\hline & 3 & 25 & 50.0 & 25 & 50.0 & Linear-by-Linear Association & 1.034 & 1 & 0.309 \\
\hline & 4 & 27 & 54.0 & 23 & 46.0 & $\mathrm{~N}$ (valid cases) & 200 & - & - \\
\hline & Total & 112 & 56.0 & 88 & 44.0 & - & - & - & - \\
\hline
\end{tabular}

benefits from the use of GM trees (question Q2.2) were analyzed by a four-point Likert scale (4: very important; 3 : slightly important; 2: not important; 1: I do not know). The highest percentage of students from the faculty of Applied Ecology (75.3\%) and a large percentage of students from the faculty of Forestry (65.2\%) believe that "Use of less pesticides in forest plantations" is the most important benefit (Tab. 3). On the other hand, a "Higher tree productivity" was the major benefit for most forestry students $(66.7 \%)$ and for a high percentage of ecology students $(71 \%)$. It is worth to notice that for all the benefits listed in the questionnaire, the answer 4 ("very important") was the most frequent, with the only exception of the benefit "Higher pulping efficiency", where answer 3 ("slightly important") had the highest percentage in both faculties (Tab. $3)$.

Tab. 6 - Results of the survey on students' attitudes toward potential hazards of commercial use of GM trees.

\begin{tabular}{|c|c|c|c|c|c|c|c|c|}
\hline \multirow[b]{2}{*}{ Potential Hazard } & \multicolumn{4}{|c|}{$\begin{array}{c}\text { Faculty of Forestry } \\
\text { (\% of answers) }\end{array}$} & \multicolumn{4}{|c|}{$\begin{array}{c}\text { Faculty of Applied Ecology } \\
\text { (\% of answers) }\end{array}$} \\
\hline & 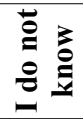 & 之莡 & 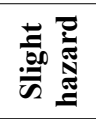 & 号: & 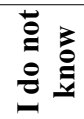 & Z记 & 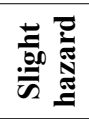 & 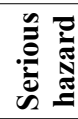 \\
\hline Forest trees less fit & 1.5 & 3.5 & 48.5 & 46.5 & 8.0 & 4.5 & 43.2 & 44.2 \\
\hline $\begin{array}{l}\text { Forest trees more vulne- } \\
\text { rable to viral diseases }\end{array}$ & 1.0 & 6.5 & 29.6 & 62.8 & 5.5 & 3.0 & 34.5 & 57.0 \\
\hline $\begin{array}{l}\text { Higher rates of soil } \\
\text { decomposition }\end{array}$ & 7.0 & 20.0 & 46.5 & 26.5 & 14.5 & 13.5 & 51.0 & 21.0 \\
\hline $\begin{array}{l}\text { More pesticide resistant } \\
\text { forest species }\end{array}$ & 7.6 & 15.2 & 41.9 & 35.4 & 10.0 & 13.0 & 37.0 & 40.0 \\
\hline $\begin{array}{l}\text { More use of broad } \\
\text { spectrum herbicides }\end{array}$ & 5.5 & 9.5 & 27.1 & 57.8 & 10.0 & 1.5 & 28.0 & 60.5 \\
\hline Loss of biodiversity & 2.5 & 8.0 & 18.0 & 71.5 & 8.0 & 2.0 & 14.5 & 75.5 \\
\hline $\begin{array}{l}\text { Adverse effects on } \\
\text { bio-trophic processes } \\
\text { of host ecosystems }\end{array}$ & 9.0 & 6.0 & 30.0 & 55.0 & 9.5 & 3.5 & 23.5 & 63.5 \\
\hline $\begin{array}{l}\text { Increased cost of con- } \\
\text { trolling pest outbreaks }\end{array}$ & 9.0 & 10.0 & 41.5 & 39.5 & 9.5 & 8.5 & 40.0 & 42.0 \\
\hline $\begin{array}{l}\text { Cultural adaptation to } \\
\text { changing biodiversity } \\
\text { conditions }\end{array}$ & 13.0 & 11.5 & 32.5 & 43.0 & 14.2 & 13.2 & 39.1 & 33.5 \\
\hline
\end{tabular}

commercial planting of GM trees (Q2.3) was analyzed using a Chi-square test (Tab. 5). No significant correlation was found for students of both faculties (asymptotic significance $>0.05$ in both cases). However, a nonsignificant relationship $(\mathrm{p}=0.051)$ between knowledge of GM trees and acceptance their commercial planting was observed for students of the Faculty of Forestry. Cross tabulation of data for questions Q1.1 and Q2.3 revealed an asymptotic significance of 0.015 $\left(\chi^{2}=5.902\right)$ for students from the Faculty of Forestry and $0.949\left(\chi^{2}=0.004\right)$ for those of the Faculty of Applied Ecology.

The final part of the questionnaire was aimed at determining the perception of students about the safety of GM forest trees, through two questions:

- Q3.1 "Which of the following issues concerns you the most regarding the use of transgenic forest crops?"

- Q3.2 "Which of the following cases do you think may constitute a hazard when using a transgenic forest crop?"

As for question Q3.1, a list of nine pre-determined possible answers was proposed, though students had the possibility to provide no answer at all or even a custom answer not included in the list. The most concerning issue related with the use of GM trees was the "Loss of biodiversity" for students from both faculties (Fig. 2), followed by "More use of broad spectrum herbicides" and "Forest trees more vulnerable to viral diseases", both with over 20 answers.

As for question Q3.2, students were requested to rank the potential hazards related to the commercial use of GM trees using a four-point Likert scale (4: serious hazard; 3: slight hazard; 2: no hazard; 1: I do not know). As reported in Tab. 6, 70 to $90 \%$ of the students' answers were ranked in the " 4 : serious hazard" or " 3 : slight hazard" categories. This means that all the listed hazards associated with the use of GM trees were considered as potentially dangerous by the students of both faculties, with slight differences. However, most concerning hazards 
(over $60 \%$ of answers ranking in the category "4: serious hazard") were the "Loss of biodiversity" for students from both faculties, "Forest trees more vulnerable to viral diseases" for forestry students and "Adverse effects on bio-trophic processes of host ecosystems" for ecology students.

\section{Conclusions}

No significant differences in responses to this survey were found between students from Faculty of Forestry and Faculty of Applied Ecology, despite the fact study programs and educational background are in the area of natural sciences in both cases. All students showed a good knowledge of GM trees and all agreed that the use of GM trees would be very important for their country. As expected, the level of knowledge of GM trees increased along the study course, as a consequence of the information acquired over their educational career.

Based on the results of the survey carried out, most important benefits of the use of GM trees were "use of less pesticides in forest plantations" and "higher tree productivity". In general, however, all stated benefits were mostly ranked as slightly or very important by students of both faculties. Overall, 50 to $60 \%$ of students were willing to accept planting of GM trees for commercial use and purchase their final products, with forestry students more willing to accept commercial planting than purchase final products from GM trees, and vice-versa for ecology students. No correlation was found between the students' acceptance of commercial use of GM trees and their study year. However, for students of the Faculty of Forestry a relationship between knowledge of GM trees and their acceptance for commercial planting was observed, though not statistically supported.

Most safety issues related with the commercial use of GM trees were ranked as serious or slight hazards, and the most concerning issue was the "loss of biodiversity", as already reported by previous surveys (Nonić et al. 2014). Future research will be extended to students from other countries over Europe, as well as to students with different educational backgrounds (e.g., social sciences).

\section{Acknowledgements}

The authors wish to thank Jelena Nedeljkovic for her help in data analysis. This research was carried out within the COST Action FP0905: "Biosafety of forest transgenic trees: improving the scientific basis for safe tree development and implementation of EU policy directives" (WG3: Socio-economic implications of and recommendations for the use of GM trees).

\section{References}

FAO (2004). Preliminary review of biotechnology in forestry, including genetic modification. United Nations, Food and Agriculture Organization, Rome, Italy, pp. 118.

Häggman H, Raybould A, Borem A, Fox T, Handley L, Hertzberg M, Lu MZ, Macdonald P, Oguchi T, Pasquali G, Pearson L, Peter G, Quemada $\mathrm{H}$, Séguin $\mathrm{A}$, Tattersall $\mathrm{K}$, Ulian $\mathrm{E}$, Walter $\mathrm{C}$, McLean M (2013). Genetically engineered trees for plantation forests: key considerations for en- vironmental risk assessment. Plant Biotechnology Journal 11: 785-798. - doi: 10.1111/pbi.12 100

Harfouche A, Meilan R, Altman A (2011). Tree genetic engineering and applications to sustainable forestry and biomass production. Trends in Biotechnology 29 (1): 9-17. - doi: 10.1016/j.tib tech.2010.09.003

IBM (2011). IBM SPSS Statistics for Windows verion 20.0. IBM Corporation, Armonk, NY, USA.

Milovanović J, Šijačić-Nikolić M (2006). Global climate changes and forest genetic resources conservation. In: Proceedings of the International Conference "Sustainable use of forest ecosystems. The Challenge of the $21^{\text {st }}$ Century". Donji Milanovac (Serbia) 8-10 November 2006. Book of abstract, pp. 142.

Nonić M, Vettori C, Boscaleri F, Milovanović J, Šijacić-Nikolić M (2012). Genetically modified trees - state and perspectives. Genetika 44 (2): 429- 440. - doi: 10.2298/GENSR1202429N

Nonić M, Nedeljković J, Radojević U, Vettori C, Šijačić-Nikolić M (2014). State and perspectives of genetically modified trees in some Western Balkan countries. In: "Tree Biotechnology" (Ramawat KG, Mérillon JM, Ahuja MR eds). CRC Press (in press). [online] URL: http://www.crcpress.com/product/isbn/9781466597143

Steinbrecher RA, Lorch A (2008). Genetically engineered trees and risk assessment: an overview of risk assessment and risk management issues. Federation of German Scientists, Berlin, Germany, pp. 1-12. [online] URL: http://www.econ exus.info/sites/econexus/files/GE-Tree FGS 200 8.pdf 